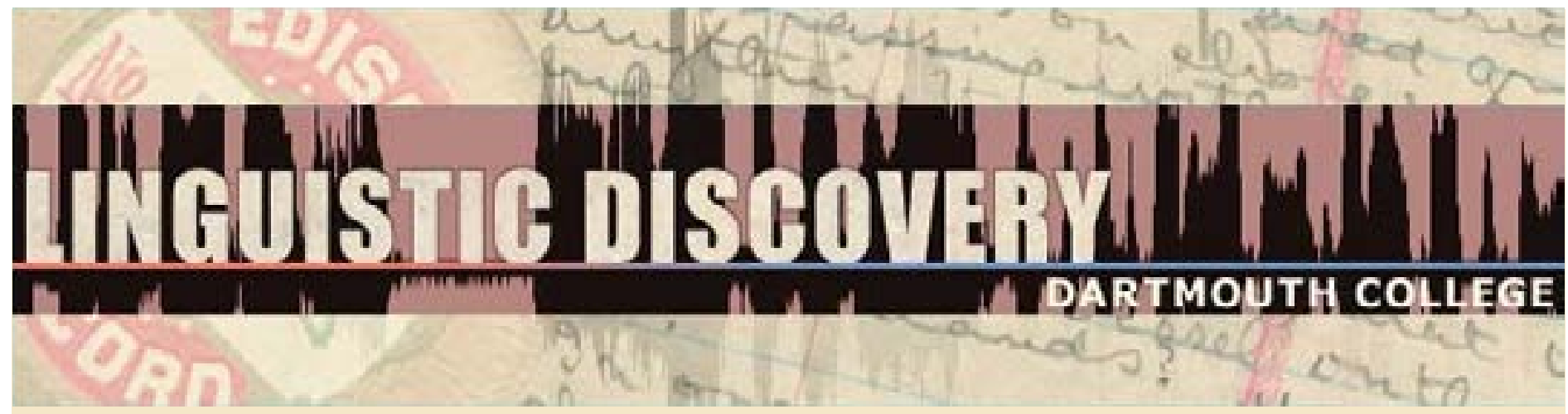

\begin{tabular}{|l|}
\hline Volume 9 \\
Issue 2 \\
2011 \\
\hline
\end{tabular}

\title{
Ditransitive Constructions in Laz
}

René Lacroix

Max Planck Institute for Evolutionary Anthropology, Leipzig

doi: 10.1349/PS1.1537-0852.A.395

url: http://journals.dartmouth.edu/cgi-bin/WebObjects/ Journals.woa/1/xmlpage/1/article/395

\section{Linguistic Discovery}

Published by the Dartmouth College Library Copyright to this article is held by the authors. ISSN 1537-0852 linguistic-discovery.dartmouth.edu 


\section{Ditransitive Constructions in Laz \\ René Lacroix \\ Max Planck Institute for Evolutionary Anthropology, Leipzig}

\section{Introduction}

This paper examines the ditransitive constructions in Laz. Laz belongs to the South Caucasian language family, which also includes Mingrelian, Georgian and Svan. It is spoken mainly in North-East Turkey. The last official Turkish census dates back to 1965 and gives the number of 85,108 speakers (Andrews 1989:176). Feurstein (1983) estimates 250,000 speakers. Laz is an unwritten and endangered language. Almost all speakers are bilingual with Turkish. Although young people still understand Laz, most of them speak only Turkish.

According to some scholars (Marr 1910; Čikobava 1936), Laz is divided into three main dialects. Kutscher (2001) distinguishes four dialects. The corpus on which this work is based is from the dialect of Arhavi. It includes published texts (Dumézil 1937, 1967, 1972; Žyent'i 1938; Q'ipšize 1939; K'art'ozia 1972, 1993) as well as data collected by the author in Turkey from native speakers since 2004. Although most data come from spontaneous texts, some have been elicited. A preliminary study of ditransitive constructions in Laz is provided in Lacroix (2009), a description of the Arhavi dialect. ${ }^{1}$

The paper is organized as follows. Section 2 examines the coding properties of core arguments in intransitive and monotransitive constructions. Ditransitive verbs are of two lexical types: in section 3, I consider non-derived ditransitive verbs; in section 4, I examine applicative ditransitive verbs. Section 5 is dedicated to the question of the distribution of object properties in ditransitive constructions and to their alignment type. One typologically interesting characteristic of the verb 'give' in Laz is its pattern of agreement: person-marking of the Theme and Recipient depends on a person hierarchy. Cross-linguistically, it is much more common for person hierarchies to determine the marking of the $\mathrm{A}$ and $\mathrm{O}$ arguments. This point is examined in section 6. The verb 'give' may take one of two preverbs, $m e$ - and $m o-$, the distribution of which is reminiscent of direct/inverse markers; this question is considered in section 7. Finally, it is shown in section 8 that in the construction known as 'inversion', the Recipient must be demoted to an oblique position.

\section{Coding Properties}

\subsection{Morphology of cross-referencing affixes}

The morphological structure of finite verb forms in Laz may be summarized as follows:

\footnotetext{
${ }^{1}$ The transcription of Laz used here includes the following symbols: $\check{Z}=\left[\mathrm{d}_{3}\right], z=[\mathrm{dz}], c=$ [ts]; the apostrophe indicates glottalized consonants. The phoneme /r/ tends to drop; consequently, some morphemes may appear with /r/ in some example, and without /r/ in another. Abbreviations are given at the end of the article.
} 


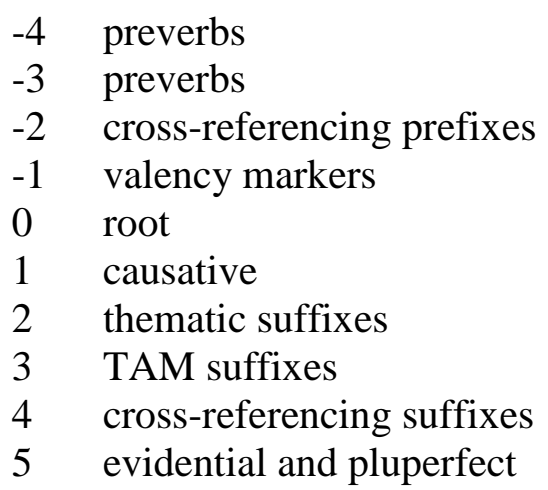

According to their function, preverbs can be divided into two groups. Most preverbs (more than thirty) are used to derive lexical items and have basically a spatial meaning; compare for instance $e$-xt- 'go up', ge-xt- 'go down', gama-xt- 'go out', ama-xt- 'enter', dolo-xt- 'go down in a vertical, narrow place' and $e \check{s} a-x t$ - 'go out from a narrow place'. Four preverbs are used in the formation of tenses; they are also sensitive to polarity, information structure and sentence type.

There are two sets of cross-referencing affixes ('Set I' and 'Set II'), glossed by Roman numerals. As we will see in section 2.2, Set I cross-references (among other things) the transitive subject while Set II cross-references (among other things) the object. ${ }^{2}$

Table 1 gives the paradigm of Set I affixes, without phonologically conditioned allomorphs. The verb -zir- 'see' in the present tense and with a $3^{\text {rd }}$ person object is taken as an example $\left(3^{\text {rd }}\right.$ person objects are not marked on the verb; see table 2). This verb takes the thematic suffix -om. ${ }^{3}$ In the future, a set of suffixes cumulate the realization of person and tense; these are omitted from the table for the sake of simplicity.

\begin{tabular}{|c|c|c|c|}
\hline & CR prefixes & CR suffixes & examples \\
\hline $1 \mathrm{sg}$ & $b-$ & & b-zir-om 'I see him' \\
\hline $2 \mathrm{sg}$ & & & 3ir-om 'you ${ }_{\mathrm{sg}}$ see him' \\
\hline $3 \mathrm{sg}$ & & $-S / n / u$ & 3ir-om-S 'he sees him' \\
\hline $1 \mathrm{pl}$ & $b-$ & $-t$ & $b$-zir-om-t'we see him’ \\
\hline $2 \mathrm{pl}$ & & $-t$ & 3ir-om-t 'you $\mathrm{pl}_{\mathrm{pl}}$ see him’ \\
\hline $3 \mathrm{pl}$ & & -an/nan/es/n & 3ir-om-an 'they see him' \\
\hline
\end{tabular}

Table 1: Set I cross-referencing affixes

\footnotetext{
${ }^{2}$ Set I and Set II affixes are called 'subject' and 'object' markers by some authors (Tschenkéli 1958; Holisky 1991; Harris 1985; Tuite 1998; Boeder 2005). However, in the construction known as 'inversion', the argument crossreferenced by so-called 'object' markers (i.e. Set II affixes) exhibits subject properties (see section 8). Consequently, I prefer to use the more neutral terms 'Set I' and 'Set II' affixes, which do not prejudge the actual functions of these affixes.

${ }^{3}$ Thematic suffixes appear in certain tenses, including the present, the imperfect and the subjunctive. There is a small class of verbs which do not take thematic suffixes.
} 
In $3^{\text {rd }}$ person singular and plural, the choice between the different allomorphs is conditioned by verb class and tense. For instance, the verb illustrated in (5) below belongs to another class than 'see'; it takes the $3^{\text {rd }}$ person singular suffix $-n$. In past tenses, the suffix is $-u$ for all verbs (see ex.1).

Table 2 gives the combinations of Set I and Set II affixes as they appear in transitive verb forms. Phonologically conditioned allomorphs are not displayed. There is no difference in Set II between $3^{\text {rd }}$ person singular and $3^{\text {rd }}$ person plural. The choice between the suffixes separated by a slash is again conditioned by verb class and tense. Suffixes of the future tense are ignored. ${ }^{4}$

\begin{tabular}{|l|l|l|l|l|l|}
\hline I/II & \multicolumn{1}{|c|}{$1 \mathrm{sg}$} & \multicolumn{1}{|c|}{$2 \mathrm{sg}$} & \multicolumn{1}{c|}{3} & \multicolumn{1}{c|}{$1 \mathrm{pl}$} & \multicolumn{1}{c|}{$2 \mathrm{pl}$} \\
\hline $1 \mathrm{sg}$ & & $g-$ & $b-$ & & $g-t$ \\
\hline $2 \mathrm{sg}$ & $m-$ & & - & $m-t$ & \\
\hline $3 \mathrm{sg}$ & $m-s / n / u$ & $g-s / n / u$ & $-s / n / u$ & $m$-an/nan/es/n & $g$-an/nan/es/n \\
\hline $1 \mathrm{pl}$ & & $g-t$ & $b-t$ & $g-t$ \\
\hline $2 \mathrm{pl}$ & $m-t$ & & $-t$ & $m-t$ & \\
\hline $3 \mathrm{pl}$ & $m$-an/nan/es/n & $g$-an/nan/es/n & -an/nan/es/n & $m$-an/nan/es/n & $g$-an/nan/es/n \\
\hline
\end{tabular}

\subsection{Coding properties of full NPs}

In Arhavi Laz, syntactic functions are indicated by cases and cross-referencing affixes. Sentence 1 illustrates the transitive construction. The A argument (berek) is in the ergative and is crossreferenced on the verb by a Set I affix $(-u)$; the $\mathrm{O}$ argument (ocxož) is in the absolutive and is cross-referenced by a Set II affix (which is zero in $3^{\text {rd }}$ person, as we have seen). $1^{\text {st }}$ and $2^{\text {nd }}$ person objects are overtly cross-referenced on the verb - see the prefix $k$-in example (2).

$$
\begin{aligned}
& \begin{array}{l}
\text { Bere-k ocxož } \\
\text { child-ERG comb }
\end{array} \text { PV-th'oč- } u . \\
& \text { 'The boy threw the comb.' (D37.1) }
\end{aligned}
$$

$$
\begin{aligned}
& \text { Ma si e-k-č'op-are. } \\
& \text { 1SG 2SG PV-II2-marry-FUT.I1/2SG } \\
& \text { 'I will marry you.' (D37.12) }
\end{aligned}
$$

The subject (A) triggers number agreement, contrary to the object. Thus, in (3b) below, bozopek 'the girls' is cross-referenced by the plural suffix -an; in (3c), by contrast, the plurality of the object bič'epe 'the boys' is not indicated in the verb.

\footnotetext{
${ }^{4}$ In Lacroix (to appear (a)), a diachronic scenario is put forward which explains the distribution of the suffixes in table 2 .

${ }^{5}$ Abbreviations of the references of the examples are given at the end of the article.
} 

a. Bozo-k bič’i zi-om-S.
girl-ERG boy see-TH-I3SG
'The girl sees the boy.' (inf)
b. Bozo-pe-k bič'i zi-om-an.
girl-PL-ERG boy see-TH-I3.PL
'The girls see the boy.' (inf)
c. Bozo-k bič’-epe 3i-om-S.
girl-ERG boy-PL see-TH-I3SG
'The girl sees the boys.' (inf)

The issue of number agreement concerns only $3^{\text {rd }}$ person arguments, as $1^{\text {st }}$ and $2^{\text {nd }}$ person arguments always trigger number agreement. In (4), for instance, the plurality of the second person object is marked by $-t$ :

$$
\begin{array}{lll}
\text { Ma } & \text { tkva } & g \text {-zi-om- } t . \\
\text { 1sG } & \text { 2PL } & \text { II2-see-TH-1/2PL } \\
\text { 'I see you } & \text { yl.' (inf) }
\end{array}
$$

By 'transitive verb' is meant a verb taking an object ( $\mathrm{O}$ argument); a verb which does not take an object is intransitive.

Intransitive verbs may be plain or inverse. Inverse verbs take a dative subject crossreferenced by Set II affixes; they are examined in section 8. The subject of plain intransitive verbs is cross-referenced by Set I affixes. Among these verbs, some take an absolutive subject (ex.5) while others take an ergative subject (ex.6). The intransitive subject, like the transitive subject, triggers number agreement (ex.7).

$$
\begin{array}{ll}
\text { Nek'na } & \text { ge-i-nk'ol-e-n. } \\
\text { door } & \text { PV-VALi-close-TH-I3SG } \\
\text { 'The door closes.' (inf) }
\end{array}
$$

$$
\begin{aligned}
& \text { K'oči-k čind-um-S. } \\
& \text { man-ERG } \quad \text { sneeze-TH-I3SG } \\
& \text { 'The man sneezes.' (inf) }
\end{aligned}
$$

$$
\begin{array}{lll}
\text { Sum } & \text { bozo } & \text { m-ul-u-nan. } \\
\text { three } & \text { girl } & \text { PV-come-TH-I3.PL }
\end{array}
$$

'Three girls are coming.' (K'93.119)

Ergative intransitive subjects are animate, while many absolutive intransitive subjects are inanimate. Some examples are given below. The marker $i$ - which appears in some of these verbs indicates middle voice. 


\begin{tabular}{llll} 
yveck'- & 'croak' & mko- & 'yawn' \\
i-bgar- & 'cry' & murmol- & '(bear) growl' \\
i-zicin- & 'laugh' & p'et'el- & 'bleat' \\
k'arčal- & 'cluck' & xirxin- & 'neigh' \\
k'iy- & 'crow' & xrut'in- & 'snore' \\
lal- & 'bark' & xval- & 'cough' \\
myo- & 'moo' & \\
\multicolumn{4}{c}{ Table 3: Some ergative subject intransitive verbs }
\end{tabular}

inanimate subject

čxant'- 'shine'

i-čod- 'finish (intr.)'

i-gub- 'cook (intr.)'

i-monč' 'ripen (intr.)'

i-nck'- 'open (intr.)' animate subject

gur- 'die'

i-bad- 'grow old'

i-rd- '(child) grow'

$x$ - 'sit, be sitting'

xrock- '(animal) die'

Table 4: Some absolutive subject intransitive verbs

The comparison of (5) with (1) shows that the alignment of absolutive-S verbs is of the mixed type: $\mathrm{S}$ behaves like $\mathrm{O}$ with respect to case marking, but it behaves like A with respect to crossreferencing and number agreement. On the other hand, the comparison of (6) with (1) shows that the alignment of ergative- $S$ verbs is accusative: $S$ behaves like A according to case marking, cross-referencing and number agreement. This is summarized in table 5 (NA = number agreement).

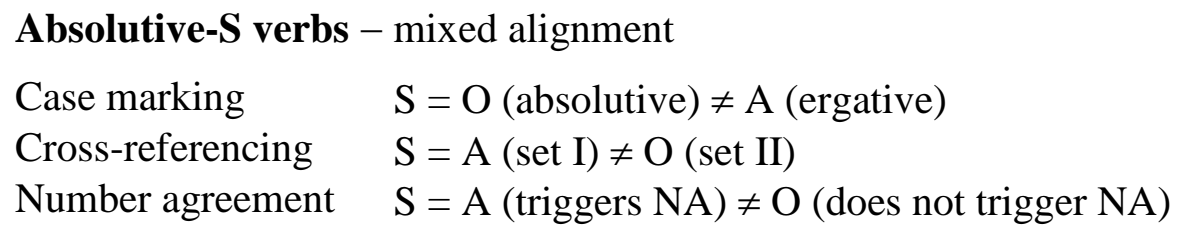

Ergative-S verbs - accusative alignment

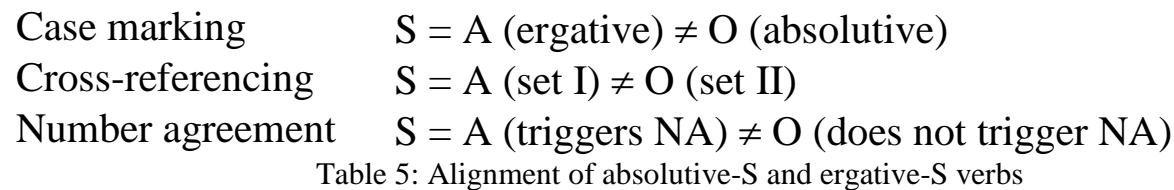

Basic word order is SOV. Word order does not indicate grammatical functions, but rather reflects information structure (see section 5.2). 


\section{$2.31^{\text {st }}$ and $2^{\text {nd }}$ person pronouns}

$1^{\text {st }}$ and $2^{\text {nd }}$ person pronouns have the same form in the ergative, absolutive and dative cases, as shown in table 6. Demonstratives are used as $3^{\text {rd }}$ person pronouns (see sentences 27 and 40 for examples).

$\begin{array}{cll} & 1^{\text {st }} \text { singular } & m a \\ \text { ergative, absolutive and dative: } & 2^{\text {nd }} \text { singular } & s i \\ & 1^{\text {st }} \text { plural } & c ̌ k u \\ & 2^{\text {nd }} \text { plural } & t k v a \\ \text { Table } 6: 1^{\text {st }} \text { and } 2^{\text {nd }} \text { person pronouns } & \end{array}$

The alignment of $1^{\text {st }}$ and $2^{\text {nd }}$ person pronouns is thus neutral with respect to case marking $(\mathrm{A}=\mathrm{O}$ $=\mathrm{S})$. Cross-referencing and number agreement, however, remain accusative. The examples below illustrate the use of the $2^{\text {nd }}$ person singular pronoun si in $\mathrm{A}, \mathrm{O}$ and $\mathrm{S}$ functions, respectively.

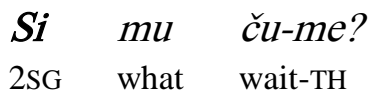

'What are you waiting for?' (D67.20)

Ma si $\quad e-k$-č'op-are.

1SG 2SG PV-II2-marry-FUT.I1/2SG

'I will marry you.' (D37.12)

$$
\begin{aligned}
& \text { Si guruni ye-i? } \\
& \text { 2SG donkey be-INT } \\
& \text { 'Are you a donkey?' (K'72.144) }
\end{aligned}
$$

Notice that when a $1^{\text {st }}$ or $2^{\text {nd }}$ person affix is co-referent with an NP inflected for core syntactic case, the latter exhibits the case triggered by its function. In sentence (11), for instance, iri 'all' refers to a $2^{\text {nd }}$ person plural Recipient and takes the dative case:

$$
\begin{array}{lll}
\text { Iri-S } & \text { titotito } & m e-k \text { - } \breve{c} \text {-aten. } \\
\text { all-DAT } & \text { one_to_each } & \text { PV-II2-give-FUT.1/2PL } \\
\text { 'I will give one to each of you.' (D67.1) }
\end{array}
$$

\section{Non-derived Ditransitive Verbs}

A ditransitive construction can be defined as a construction consisting of a (ditransitive) verb, an Agent, a Recipient and a Theme (Malchukov et al. 2007:2). In Laz, the coding properties of ditransitive constructions are as follows. The Agent has the same properties as in monotransitive constructions: it is in the ergative (usta-musi $i-k$ in example 12) and is cross-referenced by Set I affixes (here $-u$ ). The Theme is in the absolutive (tokmagi) and the Recipient in the dative (beres). In most occurrences of ditransitive constructions, Set II cross-references the Recipient 
(examples 13 and 14). As we will see in section 6, however, the verb 'give' allows a human Theme; in that case, Set II may cross-reference the Theme, depending on a person hierarchy. Neither the Theme nor the Recipient can trigger number agreement in the verb, as will be illustrated in section 5 .

$\begin{array}{lllll}\text { Usta-muši-k } & \text { bere-s } & \text { ar } & \text { tokmayi } & \text { ko-me- } \check{c}-u . \\ \text { master-POSS3SG-ERG } & \text { child-DAT } & \text { one mallet } & \text { PV-PV-give-AOR.I3SG } \\ \text { 'His master gave a mallet to the child.' (D67.XII) }\end{array}$

$\begin{array}{llll}\text { Beki } & \text { miti-k } & \text { gyay } & \text { ko-m-č-asen. } \\ \text { maybe } & \text { somebody-ERG } & \text { food } & \text { PV-II1-feed-FUT.I3SG } \\ \text { 'Maybe somebody will give me food.' (D67.XX) }\end{array}$

\begin{tabular}{llll} 
Xasani-k & \multicolumn{1}{c}{ si $\quad$ mčxui } & $k o-m e-k-\check{c}-u$. \\
Hasan-ERG & 2SG & sheep & PV-PV-II2-give-AOR.I3SG \\
'Hasan has given the sheep to you.' (inf)
\end{tabular}

The term 'ditransitive' extends to constructions including arguments whose coding properties are the same as those of the prototypical ditransitive construction, but whose semantic roles differ to some extent from those of the prototypical ditransitive construction, as in (15).

\begin{tabular}{llllll} 
Padišahi-k & \multicolumn{1}{c}{ 'ut'a } & bere-s & mut & var & k'itx-u. \\
sultan-ERG & little & child-DAT & something & NEG & ask-AOR.I3SG \\
'The sultan did not ask anything to the youngest child.' (D37.I)
\end{tabular}

The Recipient argument has a special syntactic status. Like the core terms A, O and S, it is crossreferenced on the verb, and hence cannot be considered as an oblique. On the other hand, it differs from $\mathrm{A}, \mathrm{O}$ and $\mathrm{S}$ arguments by its dative marking. This suggests recognizing a fourth core syntactic role, which can be symbolized by E (standing for 'extension to core'), following Dixon and Aikhenvald (2000:3). E arguments can also appear with intransitive verbs (see ex.20b below).

The verbs 'give', 'feed, give (food)' and 'ask' illustrated above belong to the small class of non-derived, lexically specified ditransitive verbs. A further example is gama- $\check{c}^{-}$'sell'. As can be seen, the verbs 'give', 'feed' and 'sell' use the same root; they differ only with respect to the preverb. Generally, a given verb uses the same preverb throughout its entire paradigm. 'Give' is exceptional in that it has two preverbs, $m o$ - and $m e$-; their use is examined in section 7.

Beside the verbs presented above, some applicative verbs may be considered as synchronically non-derived, inasmuch as they do not have any monotransitive counterpart. This is the case of $u-c$ 'v- 'tell something to somebody' (ex.16; /v/ disappears before a round vowel). There is no such verb as $*^{\prime} c^{\prime} v$-. The monotransitive verb 'say something' uses another root (ex.17). The applicative construction is examined in the next section.

$$
\begin{array}{lcc}
\text { Mutu } & \text { var } & \text { m-i-c'-u. } \\
\text { something } & \text { NEG } & \text { II1-VAL } u \text {-tell-AOR.I3SG } \\
\text { 'He did not tell me anything.' (D67.LV) }
\end{array}
$$




$$
\begin{array}{lll}
\text { 'Var-ya' } \quad t k-u & c a n a-k . \\
\text { NEG-QUOT } & \text { say-AOR.I3SG } & \begin{array}{l}
c \text { robin-ERG } \\
\text { '"No", the robin said.' (Ž.108) }
\end{array}
\end{array}
$$

\section{The Applicative Derivation}

The applicative is a verbal derivation which, when applied to a monotransitive verb, yields a ditransitive verb. Section 4.1 examines the morphosyntax of this derivation and section 4.2 , its semantics.

\subsection{Morphosyntax}

Sentence (18b) illustrates an applicative ditransitive construction. It can be compared with (18a), the corresponding non-derived monotransitive construction. In (18b), case marking of the A and $\mathrm{O}$ arguments is the same as in (18a), but the Set II affix cross-references the applicative argument (bere-mušis 'his son'), which is marked by the dative case. Furthermore, the verb contains a mark of applicative derivation $(u$-). Neither the object nor the applicative argument can trigger number agreement in the verb (cf. dušmanepes 'enemies' and tipe 'heads' in 19). The applicative argument, thus, has the same coding properties as the Recipient of non-derived ditransitive verbs.

$$
\begin{aligned}
& \text { a. Baba-k oxoi do-k'od-u. } \\
& \begin{array}{l}
\text { father-ERG house PV-build-AOR.I3SG } \\
\text { 'The father built a house.' (inf) }
\end{array} \\
& \text { b. Baba-k bee-muši-s oxoi } \quad d-u-k \text { 'od- } u \text {. } \\
& \begin{array}{l}
\text { father-ERG child-POSS3SG-DAT house PV-II3.VAL } u \text {-build-AOR.I3SG } \\
\text { 'The father built a house for his son.' (inf) }
\end{array}
\end{aligned}
$$
b. Baba-k bee-muši-s oxoi d-u-k'od-u. father-ERG child-POSS3SG-DAT house PV-II3.VAL $u$-build-AOR.I3SG 'The father built a house for his son.' (inf)

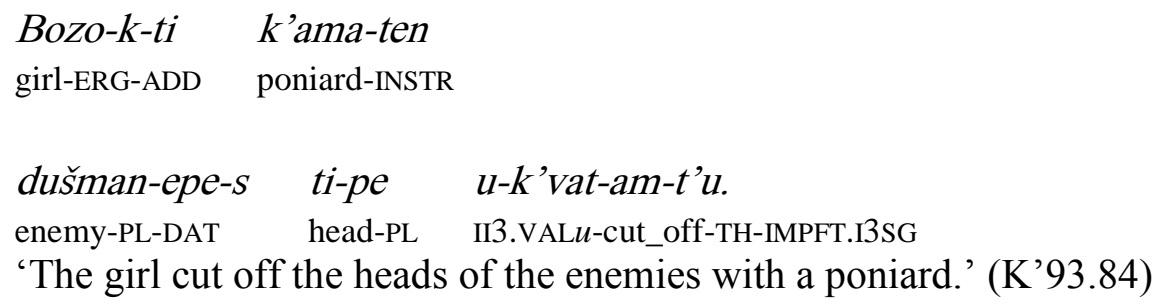

The morpheme $u$ - in (18b) and (19) can be analyzed as a portmanteau indicating both applicative derivation and Set II $3^{\text {rd }}$ person. The applicative marker is segmentable as $i$ - when the applicative argument is $1^{\text {st }}$ or $2^{\text {nd }}$ person:
$m-i-k$ 'od-u
II1-VAL $u$-build-AOR.I3SG
'he built it for me'
g-i-k'od-u
II2-VAL $u$-build-AOR.I3SG
'he built it for you'
$u-k^{\prime}$ od-u
II3.VAL $u$-build-AOR.I3SG
'he $\mathrm{i}_{\mathrm{i}}$ built it for him ${ }_{\mathrm{j}}$ ' 
To distinguish the applicative marker from the middle marker $i-$, I gloss the former by VAL $u$ (valency marker $u$-) and the latter by VAL $i$ - (valency marker $i$-).

The applicative derivation can also apply to intransitive verbs; compare (20a) and (20b). In that case, the verb has two core arguments: a subject and an E argument.
a. I-čališ-i!
VAL $i$-work-IMP
'Work!' (inf)
b. Sum c'ana-s ma m-i-čališs-i!
three year-DAT 1SG II1-VAL $u$-work-IMP
'Work for me for three years!' ${ }^{\prime}(Z ̌ .27)$

Verbs containing the marker $u$ - may be lexicalized, as in $g y-u$-škv- 'swallow', which takes no applicative argument:

$$
\begin{aligned}
& \text { Mgey-epe-k puگ̌i-š xorci k'ala bere-ti gy-u-škv-es. } \\
& \text { wolf-PL-ERG cow-GEN meat with child-ADD PV-II3.VAL } u \text {-swallow-AOR.I3.PL } \\
& \text { 'The wolves swallowed the cow's meat and the boy.' (D67.2) }
\end{aligned}
$$

Usually, the term applicative is used in languages where the applicative argument is promoted to object position (Peterson 2007:39). This is not the case in Arhavi Laz: in this variety, the object is in the absolutive, while the applicative argument is in the dative. ${ }^{7}$ Some authors, however, have extended the notion of applicative to include non-canonical applicative mechanisms (see e.g. Dixon and Aikhenvald 2000:15). I retain this solution.

The Laz dialect spoken in Ardeşen has lost the dative and ergative cases (Dumézil 1972:32; Kutscher 2001:11). As a consequence, neither the applicative argument nor the object are casemarked. In this variety, then, the applicative construction is closer to a prototypical applicative. Compare in this respect (22a), taken from Ardeşen Laz, with (22b), from Arhavi Laz.

a. Ardeşen dialect

$$
\begin{array}{llll}
\text { Mtuti } & \text { arkadaši-muši } & \text { uži } & k \text {-el-u-d-u. } \\
\text { bear } & \text { friend-POSs3sG } & \text { ear } & \text { PV-PV-II3.VAL } u \text {-put-AOR.I3SG }
\end{array}
$$

'The bear applied his ear on his friend.' (D72.4)

\footnotetext{
${ }^{6}$ As we see in this example, the dative may be used to form adjuncts: sum c'ana-s 'three years', oxoi-s 'at home', etc.

${ }^{7}$ As a consequence, the applicative derivation does not transitivize intransitive verbs. The verb in (20b) is considered here as intransitive.
} 
b. Arhavi dialect

Mtuti-k arkadaši-muši-s uži el-u-d-u.

bear-ERG friend-POSS3SG-DAT ear PV-II3.VAL $u$-put-AOR.I3SG

'The bear applied his ear on his friend.' (D72.4)

Additional examples of applicative ditransitive verbs in the Arhavi dialect are listed below (the element before $u$ - is a preverb).

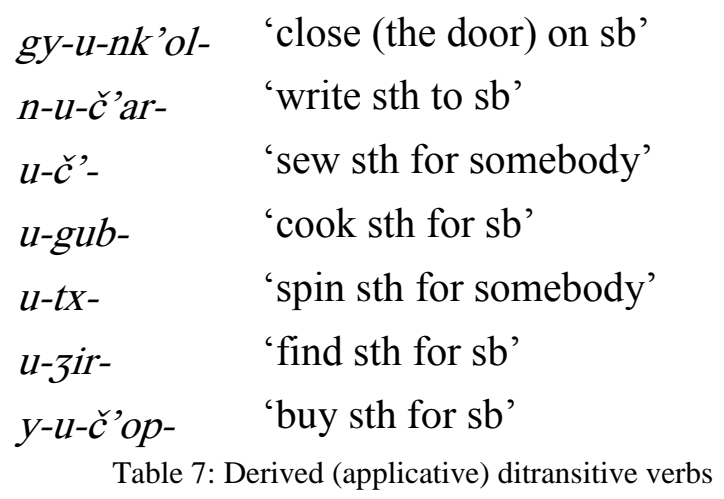

The monotransitive verb corresponding to $m-u-\gamma^{-}$'bring something to somebody' is a middle verb (it takes the valency marker $i$-). Compare the following two examples:

a. monotransitive (middle)

$\begin{array}{lll}\text { Oxorža-k } & \text { porča } & \text { ko-mo-i- }-\boldsymbol{-} \text { - } . \\ \text { woman-ERG } & \text { dress } & \text { PV-PV-VALi-bring-AOR.I3SG }\end{array}$

'The woman brought the dress.' (Ž.89)

b. ditransitive (applicative)

\begin{tabular}{|c|c|c|c|}
\hline $\begin{array}{l}A r \\
\text { one }\end{array}$ & $\begin{array}{l}\text { orč'ay } \\
\text { from_Orč'i }\end{array}$ & $\begin{array}{l}k^{\prime} \text { oči-k } \\
\text { man-ERG }\end{array}$ & $\begin{array}{l}\text { oxorža-muši-s } \\
\text { woman-POSS3SG-DAT }\end{array}$ \\
\hline & $m-u-\gamma-u$ & doren. & \\
\hline & PV-II3.VA & t-bring-AOR & 3SG-EVD \\
\hline
\end{tabular}

Corresponding to $u$-yon- 'take somebody to somebody', we find both a middle and a plain monotransitive verb. There seems to be no difference in meaning between the two:

a. monotransitive (plain)

Bere mend-o-yon-es.

child PV-VAL $o$-take-AOR.I3.PL

'They took the child.' (Ž.13) 
b. monotransitive (middle)

Bič $i-t i$ mend-i-yon-es.

boy-ADD PV-VALi-take-AOR.I3.PL

'They took the boy too.' (Ž.50)

c. ditransitive (applicative)

Padišahi-š bere-s mend-u-yon-u.

sultan-GEN child-DAT PV-II3.VAL $u$-take-AOR.I3SG

'He took her to the sultan's son.' (D67.VIII)

The verbs formed on the roots $-\gamma$ - and -yon- differ as to the semantics of the Theme: $-\gamma$ - is used with a Theme which cannot move by itself and -yon- with a Theme which can move by itself (an animate being, but also a car, a boat, or water flowing through a canal). There is thus an opposition between ont'uleša ck'ai komoigi 'bring water to the field (for instance in a bottle, for me to drink)' and ont'uleša ck'ai komoyoni 'let the water come to the field (through the canal)' (examples from my informant).

\subsection{Semantics}

The applicative in $u$ - expresses different types of beneficiary: 'plain beneficiary' (do something to amuse/please somebody), 'deputative beneficiary' (do something in somebody's place) and 'recipient beneficiary' (create something and give it to somebody) (Van Valin and LaPolla 1997:384). These various beneficiaries are illustrated below.

Plain beneficiary

Hasteri biyapa-ti u-bir-am-s...

such song-ADD II3.VAL $u$-sing-TH-13SG

'And she sings for him such a song...' (Ž.124)

(26) Deputative beneficiary

Mo-m-čc-i do ma do-g-i-naxv-a-ya.

PV-II1-give-IMP and 1SG PV-II2-VAL $u$-wash-OPT-QUOT

'Give me (the linens), I will wash it for you.' (D67.7)

Recipient beneficiary

Bozo-k xe-muši-te hentepe-s k'ahve d-u-gub-um-s.

girl-ERG hand-POSS3SG-INSTR DEM.PL-DAT coffee PV-II3.VAL $u$-boil-TH-I3SG

'The girl makes coffee for them with her own hands.' (D37.11)

The applicative argument can also have the semantic role of maleficiary (ex.28) and allative (ex.29). 
K'ui g-i-ntxo-es nek'na-s tudele.

hole II2-VAL $u$-dig-AOR.I3.PL door-DAT under

'They have dug a hole under the door (for you to fall in it).' (K'72.128)

(lit. 'they have dug you a hole under the door')

$\begin{array}{llll}K^{\prime} \text { 'at'a } & \text { toma-s } & \text { onck'ialon-epe } & \text { ko-n-u-k'id-i! } \\ \text { each } & \text { hair-DAT } & \text { bell-PL } & \text { PV-PV-II3.VAL } u \text {-hang-IMP }\end{array}$

'Tie a bell to each hair!' (Ž.25)

Example (29) shows that in Laz, the applicative construction is not restricted to human beings, as it is in other languages (Polinsky 2005).

Eventually, the applicative argument may have the semantic role of possessor. In (30), the $2^{\text {nd }}$ person cross-referencing prefix refers to the possessor of bee 'child'.

$$
\begin{aligned}
& \text { Bee mi-k } \quad g-i-i 1-u-y a ? \\
& \text { child who-ERG } \text { II2-VALu-kill-AOR.I3sG-QUOT } \\
& \text { 'Who killed your child?' (K'72.129) }
\end{aligned}
$$

Such examples can be analyzed as external possessor constructions (or 'possessor raising' constructions): the possessor is expressed as an independent argument instead of appearing as a genitive NP modifying the possessed NP.

\section{Object Properties and Alignment Types}

\subsection{Introduction}

Originally, the notion of alignment was applied to the comparison of the properties of the $S$ argument with those of the A and O arguments. Subsequently, it was extended to the analysis of ditransitive constructions (Dryer 1986, Croft 1990:100-108). According to Malchukov et al. (2007:3), "The most salient way in which the encoding of transitive and ditransitive constructions differs across languages is captured by the notion of alignment". Ditransitive alignment refers to the comparison of the coding and behavioral properties of the Theme (T) and Recipient ( $\mathrm{R}$ ) of the ditransitive construction with those of the object of the monotransitive construction $(\mathrm{O})$. In the indirective alignment, the Theme is treated like the $\mathrm{O}$ and differently from the Recipient $(\mathrm{O}=\mathrm{T} \neq \mathrm{R})$. This alignment type is found in German, as illustrated by (31ab). The Theme, like the monotransitive object, is in the accusative case; the Recipient is in the dative.

a. monotransitive

Ich aß den
1sG.NOM ate the.ACC
'I ate the apple.'


b. ditransitive

$\begin{aligned} & \text { Ich gab dem } \\ & \text { 1sG.NOM gave the.DAT } \\ & \text { 'I gave the child the apple.' }\end{aligned}$ child
child

In the secundative alignment, the Recipient is treated like the $\mathrm{O}$ and differently from the Theme $(\mathrm{O}=\mathrm{R} \neq \mathrm{T})$. This alignment type is found in West Greenlandic (Fortescue 1984:193, 88), as shown in (32a-b). The Recipient, like the monotransitive object, is in the absolutive; the Theme is in the instrumental.

a. monotransitive

$\begin{array}{lll}\text { Piita- } p & \text { takurnarta. } q & \text { tuqup-paa? } \\ \text { Peter-ERG.SG } & \text { stranger.ABS.SG } & \text { kill-INT.3SG } \rightarrow \text { 3SG } \\ \text { 'Did Peter kill the stranger?' } & \end{array}$

b. ditransitive

$\begin{array}{llll}\text { (Uuma) Niisi } & \text { aningaasa-nik } & \text { tuni-vaa. } \\ \text { (that.ERG) Nisi } & \text { money-INSTR.PL } & \text { give-IND.3SG } \rightarrow \text { 3SG } \\ \text { 'He gave Nisi money.' } & \end{array}$

In the neutral alignment, the $\mathrm{O}$, the Theme and the Recipient are encoded in the same way $(\mathrm{O}=$ $\mathrm{R}=\mathrm{T}$ ). This alignment type is found in Dagaare (Bodomo 1997:41-42), as illustrated in (33a-b).
a. monotransitive
O na ngme ma la.
he FUT beat me FACTUAL
'He will beat me.'
b. ditransitive

$\begin{array}{llllll}O & \text { ko } & \text { ma la } & \text { la } & \text { gane. } \\ \text { he give.PERF me FACTUAL } & \text { DEF } & \text { book } \\ \text { 'He gave me the book.' }\end{array}$

In the following section, I consider the distribution of object properties in ditransitive constructions in Laz and their alignment type, taking into account case marking, crossreferencing, number agreement and two behavioral properties: relativization and promotion to subject position. I consider also the constituent order of ditransitive constructions; this, however, cannot serve as a diagnostic for the alignment. 


\subsection{Object properties}

\section{Case marking}

In Laz, with respect to case marking, the Theme behaves like the $\mathrm{O}$ and differs from the Recipient: $\mathrm{T}$ and $\mathrm{O}$ are in the absolutive, while $\mathrm{R}$ is in the dative (ex.34a-b).
a.
Bozo-k biči-s ar mack'indi ko-me-č-u.
girl-ERG boy-DAT one ring PV-PV-give-AOR.I3SG

'The girl gave a ring to the young man.' (Ž.77)
b. BOZo-k k'inči zir-om-S.
girl-ERG bird see-TH-I3SG

'The girl sees the bird.' (inf)

Thus, with respect to case marking, the alignment is indirective $(\mathrm{O}=\mathrm{T} \neq \mathrm{R})$.

\section{Cross-referencing}

In ditransitive constructions, human Themes do not occur frequently; for this reason, the Theme is most often $3^{\text {rd }}$ person. I consider here such cases. Constructions with a $1^{\text {st }}$ or $2^{\text {nd }}$ person Theme are examined in the next section.

In a ditransitive construction with a $3^{\text {rd }}$ person Theme, the Recipient behaves like the O: both are cross-referenced by Set II affixes, as shown in (35a-b). The Theme, on the other hand, is not cross-referenced. ${ }^{8}$
a. Bozo-k ma m-zir-om-s.
girl-ERG 1SG II1-see-TH-I3SG
'The girl sees me.' (inf)
hoja-ERG 1SG PV-II1-give-AOR.I3SG letter
'The hoja gave me a letter.' (Ž.9)
b. Xő̌a-k ma mo-m-č-u kart'ali.

This corresponds to a secundative alignment $(\mathrm{O}=\mathrm{R} \neq \mathrm{T})$.

\section{Number agreement}

As far as number agreement is concerned, there is no contrast between the monotransitive object, the Theme and the Recipient: neither of them triggers number agreement (when $3^{\text {rd }}$ person). This is illustrated in (36-38).

\footnotetext{
${ }^{8}$ Since, for a $3^{\text {rd }}$ person Theme, the marker would be zero (see table 2), one could object that there is no way to know if the Theme is cross-referenced or not. However, even in cases where both the Theme and the Recipient could be overtly cross-referenced, only one of them is. See the examples in section 6.
} 
(36) No number agreement with the monotransitive object
a. Bozo-k bič'i zi-om-S.
girl-ERG boy see-TH-I3sG
'The girl sees the boy.' (inf)
b. Bozo-k bič'-epe 3i-om-S. girl-ERG boy-PL see-TH-I3SG
'The girl sees the boys.' (inf)

(37) No number agreement with the Recipient
a. Bozo-k bič'i-s ar mack'indi ko-me-č-u. girl-ERG boy-DAT one ring PV-PV-give-AOR.I3SG
'The girl gave a ring to the young man.' (Ž.77)
b. Bozo-k bič'-epe-s ar mack'indi ko-me-č-u. girl-ERG boy-PL-DAT one ring PV-PV-give-AOR.I3SG 'The girl gave a ring to the young men.' (inf)

(38) No number agreement with the Theme
a. $\quad$ see $(37 a)$
b. Bozo-k biči-s mack'ind-epe ko-me-č-u. girl-ERG boy-DAT ring-PL PV-PV-give-AOR.I3SG 'The girl gave rings to the young man.' (inf)

With respect to number agreement, the alignment is thus neutral $(\mathrm{O}=\mathrm{R}=\mathrm{T})$.

\section{Relativization}

Example (39b) shows that the monotransitive object can be relativized.
a. Izmože zir-u. dream see-AOR.I3SG
'He had a dream.' (D67.IV)
b. [[na-zir-u] izmő̌e]
SUB-see-AOR.I3SG dream
'the dream that he had' (D37.V)

In the ditransitive construction, both the Theme and the Recipient can be relativized. Examples (40b) and (41b) illustrate the relativization of the Theme with an applicative verb and a nonderived verb, respectively. The corresponding independent clauses are illustrated in the (a) examples. 
applicative verb

a. Nuri-s a oxoi do-b-u-k'od-i.

Nuri-DAT one house PV-I1-II3.VAL $u$-build-AOR

'I've built a house for Nuri.' (inf)

b. [[Nuri-S-na b-u-k'od-i] oxoi]

Nuri-DAT-SUB I1-II3.VAL $u$-build-AOR house

'the house that I've built for Nuri' (inf)

(41) non-derived verb

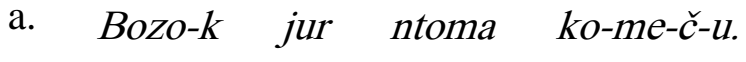

girl-ERG two hair PV-PV-give-AOR.I3SG

'The girl gave him two hairs.' (inf)

b. [[bozo-k-na me-̌r-u] jur ntoma]

girl-ERG-SUB PV-give-AOR.I3SG two hair

'the two hairs that the girl had given to him' (D37.VIII)

In (42b) and (43b), the Recipient is relativized.

applicative verb
a. Baba-k bee-muši-s oxoi $d-u-k^{\prime} o d-u$.
father-ERG child-POSS3SG-DAT house PV-II3.VAL $u$-build-AOR.I3SG
'The father has built a house for his son.' (inf)
b. [[baba-muši-k oxoi-na d-u-k'od-u] bere]
father-POSS3SG-ERG house-SUB PV-II3.VAL $u$-build-AOR.I3SG child
lit. 'the child for whom his father has built a house' (inf)

(43) non-derived verb
a. Bee-k bozo-s mack'indi ko-me-č-u. child-ERG girl-DAT ring PV-PV-give-AOR.I3SG
'The child gave the ring to the girl.' (inf)
b. [[bee-k-na mack'indi me-č-u] bozo] child-ERG-SUB ring PV-give-AOR.I3SG girl 'the girl to whom the child gave a ring' (inf)

Here again, then, the alignment is neutral $(\mathrm{O}=\mathrm{R}=\mathrm{T})$ : the $\mathrm{O}$, the Theme and the Recipient can all be relativized. 


\section{Promotion to subject position}

The transitive object can be promoted to subject position by the verbal derivation in $i$-:
a. Bozo-k nek'na ge-nk'ol-um-s.
girl-ERG door PV-close-TH-13SG
'The girl closes the door.' (inf)
b. Nek'na ge-i-nk'ol-e-n.
door PV-VAL $i$-close-TH-I3SG
'The door closes.' (inf)

In (44b), the verb with $i$ - has an anticausative reading. Verbs marked by $i$ - may have other readings, such as autocausative, autobenefactive and facilitative, all of which can be subsumed under the label 'middle' (in the sense of Kemmer 1993). In addition, verbs with $i$ - may have a passive and an antipassive reading. For further details on this derivation, see Lacroix (to appear (b)).

In a ditransitive construction, the Theme can be promoted to subject position, in contrast to the Recipient. Consider example (45), which involves the applicative verb $e l-u-k$ 'at- 'have sb go with/join sb' (from Turkish kat-).

$$
\begin{array}{llll}
\text { Baba-k } & \text { bere-muši } & \text { Xasani-s } & \text { el-u-k'at- } u \\
\text { father-ERG } & \text { child-POSs3SG } & \text { Hasan-DAT } & \text { PV-II3.VAL } u \text {-join-AOR.I3SG } \\
\text { 'The father had his son go with/join Hasan.' (inf) }
\end{array}
$$

The Theme of sentence (45) can be promoted to subject position by means of the middle derivation (ex.46). We see that the verb takes the valency marker $a$-, which indicates that it is simultaneously middle and applicative. In this example, the verb has an autocausative reading. Promoting the Recipient in (45) (Xasanis) to subject position is not possible.

$$
\begin{array}{llll}
\text { [Bere-s] } & \text { [padišahi-̌̌ } & \text { bere-ti] } & \text { el-a-k'at-u-doren. } \\
\text { child-DAT sultan-GEN } & \text { child-ADD } & \text { PV-VALa-join-AOR.I3SG-EVD } \\
\text { 'The sultan's child too joined the child.' (D67.I) }
\end{array}
$$

This point is further illustrated by the following example, which involves the non-derived verb 'give'. The Theme 'she' has been promoted to subject position.

$$
\begin{array}{ll}
\text { Hemu-s } & n-i-\check{c} \text {-ase. } \\
\text { DEM-DAT } & \text { PV-VALi-give-FUT.I3SG }
\end{array}
$$

'She will be given to him.' (K'93.122)

Table 8 schematizes the argument structure of the verbs in (45-46). 


$$
\begin{array}{cccc}
\text { applicative construction (ex.45) } & x & y & z \\
\text { middle-applicative construction (ex.46) } & \mathrm{A} & \mathrm{O} & \mathrm{E} \\
\text { Table 8: Argument structure of } u-k^{\prime} a t \text { - }^{-} x \text { joins } y \text { to } & \mathrm{S} \text { ' } & \mathrm{S} & \mathrm{E} \\
\end{array}
$$

With respect to promotion to subject position, the alignment is thus indirective: $\mathrm{O}=\mathrm{T}$ (can be promoted) $\neq \mathrm{R}$ (cannot be promoted).

The alignment of the ditransitive construction, then, shows a mismatch between case marking and promotion to subject (both indirective), cross-referencing (secundative), number agreement and relativization (both neutral). For such cases of mismatch between different properties, Malchukov et al. (2007:7) use the term mixed alignment.

\section{$1^{\text {st }}$ and $2^{\text {nd }}$ person pronouns}

Recall that $1^{\text {st }}$ and $2^{\text {nd }}$ person pronouns have the same form in the ergative, absolutive and dative cases. Consider examples (48a-c). In (48a), the $1^{\text {st }}$ person singular pronoun ma functions as the object of a monotransitive construction; in (48b), it functions as the Recipient of a ditransitive construction and in $(48 \mathrm{c})$, as the Theme.

a. monotransitive $\mathrm{O}$

$$
\begin{aligned}
& \text { Ma } \quad \text { ko-m-zir-u. } \\
& \text { 1SG PV-II1-see-AOR.I3SG } \\
& \text { 'He saw me.' (D67.55) }
\end{aligned}
$$

b. Recipient

$$
\begin{array}{llll}
\text { Xoža-k } & \text { ma } & \text { mo-m- } \check{c}-u & \text { kart'ali. } \\
\text { hoja-ERG } & \text { 1SG } & \text { PV-II1-give-AOR.I3SG } & \text { letter } \\
\text { 'The hoja gave me a letter.' (Ž.9) } &
\end{array}
$$

c. Theme

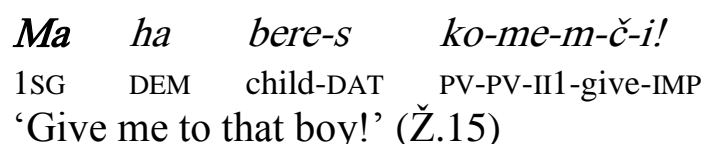

Thus, $1^{\text {st }}$ and $2^{\text {nd }}$ person pronouns display neutral alignment $(\mathrm{O}=\mathrm{T}=\mathrm{R})$.

\section{Constituent order}

Basic constituent order is SOV:

$$
\begin{array}{lll}
\text { Bere-k } & \text { ocxož } & \text { me-tk'oč- } u \\
\text { child-ERG } & \text { comb } & \text { PV-throw-AOR.I3SG } \\
\text { 'The boy threw the comb.' (D37.1) }
\end{array}
$$


According to the information structure, constituent order may undergo modifications. The main regularity is that topicalized terms are fronted (ex.50), and focalized terms occur in immediate preverbal position (ex.51).

$$
\begin{array}{llll}
\text { Nana-čkuni-a } & \text { ar } & \text { zengini-k } & n-i-x i r-u-y a . \\
\text { mother-POSS1PL-QUOT } & \text { one } & \text { rich-ERG } & \text { PV-VALi-steal-AOR.I3SG-QUOT } \\
\text { 'Our mother, a rich man took her away.' (Ž.54) }
\end{array}
$$

$$
\begin{array}{llll}
\text { Hac'i-škule } & \text { nana-skani } & \text { ma } & \text { b-ore } \\
\text { now-after } & \text { mother-Poss2sG } & 1 \mathrm{SG} & \text { I1-be } \\
\text { 'From now on, I am your mother.' (D67.11) }
\end{array}
$$

In a ditransitive construction, the most frequent orders are Agent-Theme-Recipient-Verb and Agent-Recipient-Theme-Verb. In general, the order is Theme-Recipient with definite Themes, and Recipient-Theme with indefinite Themes.

\section{Definite $\mathbf{T}(\mathbf{T}-\mathbf{R}$ order$)$}

$$
\begin{array}{llll}
\text { Avži-k } & \text { ha vesiyeti } \quad \text { oxorža-muši-s } & \text { ko-me-č-u-doren. } \\
\text { hunter-ERG } & \text { DEM will } & \text { woman-POSS3sG-DAT } & \text { PV-PV-give-AOR.I3SG-EVD } \\
\text { 'The hunter gave this will to his wife.' (D67.1) } &
\end{array}
$$

Bere-k zabun doxtori-s mend-u-yon-u-don.

child-ERG sick_person doctor-DAT PV-II3.VAL $u$-bring-AOR.I3SG-EVD

'The boy took the sick person to the doctor.' (D37.7)

\section{Indefinite $\mathbf{T}$ ( $\mathbf{R}-\mathbf{T}$ order)}

$$
\begin{aligned}
& \text { Bozo-k kčini-S jurnečdovit altun ko-me-č-u. } \\
& \text { girl-ERG old_woman-DAT fifty golden_coin PV-PV-give-AOR.I3SG }
\end{aligned}
$$

$$
\begin{aligned}
& \text { Bere-muši-s ar beyi-ši bozo ko-me-č-u. } \\
& \text { child-POSS3SG-DAT one bey-GEN girl PV-PV-give-AOR.I3SG }
\end{aligned}
$$

'He gave the girl of a bey to his son.' (Ž.14)

Constituent order does not give any information relative to alignment, since both the Theme and the Recipient are placed between the subject and the verb, as is the monotransitive object.

\section{6. $1^{\text {st }}$ and $2^{\text {nd }}$ Person Themes and the Person Hierarchy}

So far, I have examined ditransitive constructions involving a $3^{\text {rd }}$ person Theme. Constructions with a $1^{\text {st }}$ or $2^{\text {nd }}$ person Theme are rare. In my corpus, they occur primarily with the verb 'give'. When taking a human Theme, this verb generally means 'marry (a girl) to somebody'. With this 
verb, Set II cross-referencing is sensitive to the person hierarchy $1^{\text {st }}>2^{\text {nd }}>3^{\text {rd }}$ : of the Theme and the Recipient, the one which stands higher on the hierarchy is indexed; the other is not. Examples (56a-b) show that when the Theme and the Recipient are $1^{\text {st }}$ and $3^{\text {rd }}$ person, the verb crossreferences the $1^{\text {st }}$ person, whichever semantic role it has: Recipient in (56a), Theme in (56b) ('>' means 'wins over, for cross-referencing'). (57) shows that when the Theme and the Recipient are $2^{\text {nd }}$ and $3^{\text {rd }}$ person, the verb cross-references the $2^{\text {nd }}$ person, whichever semantic role it has. Finally, (58) shows that when the Theme and the Recipient are $1^{\text {st }}$ and $2^{\text {nd }}$ person, the verb crossreferences the $1^{\text {st }}$ person, whichever semantic role it has. Since Set II $3^{\text {rd }}$ person is not overtly marked with the verb 'give', no hierarchy is involved when both the Theme and the Recipient are $3^{\text {rd }}$ person.

a. $\quad 1^{\text {st }}$ Recipient $>3^{\text {rd }}$ Theme

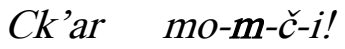

water PV-II1-give-IMP

'Give me some water!' (D37.8)

b. $\quad 1^{\text {st }}$ Theme $>3^{\text {rd }}$ Recipient

Ma ha bere-s $\quad$ ko-me-m- $\check{c}-1$ !
1SG DEM child-DAT
'GV-PV-II1-give-IMP

a. $\quad 2^{\text {nd }}$ Recipient $>3^{\text {rd }}$ Theme

Puگ̌i ko-me-k-č-are.

cow PV-PV-II2-give-FUT.I1/2SG

'I will give you a cow.' (Ž.6)

b. $\quad 2^{\text {nd }}$ Theme $>3^{\text {rd }}$ Recipient

Hemu-S me-k-č-are.

DEM-DAT PV-II2-give-FUT.I1/2SG

'I will give you to him.' (Ž.89)

a. $\quad 1^{\text {st }}$ Recipient $>2^{\text {nd }}$ Theme

Baba-skani-k si ma va mo-m-č-ase.

father-POSS2SG-ERG 2SG 1SG NEG PV-II1-give-FUT.I3SG

'Your father won't give you to me.' (inf)

b. $\quad 1^{\text {st }}$ Theme $>2^{\text {nd }}$ Recipient

Baba-k var me-m-č-am-s.

father-ERG NEG PV-II1-donner-TH-I3SG

'My father won't give me to you.' (D37.7)

Sentences (56b), (57b) and (58b) are among the rare examples of ditransitive construction where the Theme, not the Recipient, is cross-referenced. In elicitation, when asked to translate "my 
father won't give me to you", speakers give both the forms $m e-m$-č-asen (PV-II1-give-FUT.I3SG) and $m e-k$-č-asen (PV-II2-give-FUT.I3SG). In the latter case, the Recipient is cross-referenced. It should be noted that example (58b), where the Theme is cross-referenced, comes from a spontaneous text.

In almost all languages where person-marking on the verb depends on a person hierarchy, the latter concerns the marking of the $\mathrm{A}$ and $\mathrm{O}$ arguments. One exception to have been pointed out in the literature is Jamul Tiipay, a Yuman language, where the person hierarchy determines the marking of the Recipient and Theme of ditransitive constructions (Miller 2001:162-163). In Jamul Tiipay monotransitive verbs, a set of prefixes simultaneously mark the subject and the object. In ditransitive verbs, the same set of prefixes mark the subject and either the Theme or the Recipient, depending on which one is higher on the person hierarchy $1^{\text {st }}>2^{\text {nd }}>3^{\text {rd }}$. This is illustrated by examples (59)-(61). Jamul Tiipay is the only language with such an agreement pattern to be cited by Siewierska (2004).

a. $\quad 2^{\text {nd }}$ Recipient $>3^{\text {rd }}$ Theme

Xikay ny-iny-ma.

some $\quad 1 / 2$-give-PROM

'I'll give you some.'

b. $\quad 2^{\text {nd }}$ Theme $>3^{\text {rd }}$ Recipient

Nyaach maap Goodwill ny-iny-x.

I+SJ you+ABS Goodwill 1/2-give-IRR

'I'm going to give you to Goodwill.'

(61) $\quad 1^{\text {st }}$ Theme $>2^{\text {nd }}$ Recipient

Nye-shke'mak ny-a'aam-x w-i.

3/1-take_from 3/1-take_from-IRR 3-say

'She said she would take me away from you.'

The analysis of person marking in Jamul Tiipay in terms of a person hierarchy is called into question by Haspelmath (2007): "Moreover, it is not clear that the Jamul Tiipay construction falls under the definition of 'inverse' that was given in $\$ 4.1$ ('a coding pattern is called '(direct/) inverse' if the coding of the $\mathrm{R}$ and $\mathrm{T}$ arguments depends on their relative positions on the person scale $\left.\left(1^{\text {st }} / 2^{\text {nd }}>3^{\text {rd }}\right)^{\prime}\right)$. In Jamul Tiipay, the rule seems to be that any $1^{\text {st }}$ or $2^{\text {nd }}$ person object (whether R or T) is indexed on the verb, while no $3^{\text {rd }}$ person object is indexed on the verb. Thus, no reference to the relative positions of the two arguments is necessary in this case" (p.93-94). 
This leads Haspelmath to claim that verb-marked person-role inverses have been found in monotransitive constructions only (p.92). However, example (61) apparently contradicts Haspelmath's analysis: here, both the Recipient and the Theme are speech-act participants, but only the $1^{\text {st }}$ person Theme is cross-referenced, which has clearly to do with a person hierarchy.

Laz and Jamul Tiipay, then, appear to be exceptional in that their sensitivity to the person hierarchy $1^{\text {st }}>2^{\text {nd }}>3^{\text {rd }}$ concerns not the indexing of the $\mathrm{A}$ and $\mathrm{O}$ arguments, but that of the $\mathrm{T}$ and $\mathrm{R}$ arguments.

\section{The Alternating Preverbs $m e$-/mo- and Direct/Inverse Marking}

Another interesting property of the verb 'give' in Laz is the alternation between the preverbs $m e$ and $m o-$, which is determined by the person of the Recipient: $m e$ - is used when the Recipient is $2^{\text {nd }}$ or $3^{\text {rd }}$ person and $m o$ - when it is $1^{\text {st }}$ person (see ex.56-58). Me- and $m o$ - belong to the class of preverbs used to derive lexical items (see section 2.1); mo- indicates a movement toward the reference point (mo-bulur 'I am coming') and me- a movement away from the reference point (me-bulur 'I am going'). With the verb 'give', however, mo- and me- do not form two different lexemes, but alternate in the same paradigm.

Cross-linguistically, the expected situation in ditransitive constructions is for the $\mathrm{R}$ to be higher on the person hierarchy than the T. In Laz, when the R is higher than the $\mathrm{T}$ on the 1>2/3 person hierarchy, the preverb $m o$ - is used. That is, $m o$ - marks the expected situation; it can thus be compared to a direct marker. When the $\mathrm{R}$ is lower on the $1>2 / 3$ person hierarchy, me- is used, which can thus be compared to an inverse marker. Note that the preverbs do not distinguish between $2^{\text {nd }}$ and $3^{\text {rd }}$ person Recipients.

Furthermore, as direct/inverse markers, $m o$ - and $m e$ - disambiguate the roles of the participants. In a form such as $k o-m e-m-\check{c}-i$ 'give me to him' (ex.56b), the $1^{\text {st }}$ person prefix $m$ does not tell whether the $1^{\text {st }}$ person participant is the $\mathrm{T}$ or the $\mathrm{R}$. Since the preverb $m e$ - indicates that the $\mathrm{R}$ is $2^{\text {nd }}$ or $3^{\text {rd }}$ person, the prefix $m$ - can only refer to the $\mathrm{T}$. Note that the preverbs do not disambiguate all the forms: $m e-k-\check{c}$-are (ex.57) means both 'I'll give it to you' and 'I'll give you to him'.

$M o$ - and $m e$ - are orientation-marking preverbs. Cross-linguistically, orientation-marking expressions happen to be one attested source for the development of direct/inverse markers (DeLancey 2001).

\section{Inversion and Recipient Demotion}

The 'inversion' construction characterizes the four South Caucasian languages. It has been much discussed, in particular with respect to Georgian (see among others Harris 1981). In the inversion construction, the subject appears in the dative case and is cross-referenced by Set II affixes. Consider the following examples, which illustrate this construction in Laz. The verb is in the potential derivation, marked by the valency prefix $a$-. The (non-canonical) subject is in the dative case (mitis 'nobody' in 62) and is indexed by a Set II affix ( $m$ - in 63). The dative-marked argument can be considered as a subject on the basis of the fact that it shares several properties with the transitive subject (see Lacroix 2009:\$11.2). In particular, it triggers number agreement (ex.64b). 
$\begin{array}{lcll}\text { Miti-S } & \text { var } & \text { a-zir-u } & \text { mack'indi-muši. } \\ \text { somebody-DAT } & \text { NEG } & \text { VALa-find-AOR.I3SG } & \text { ring-POSS3SG }\end{array}$

'No one could find her ring.' (Ž.95)

K'oč var m-a-zir-u.

man NEG II1-VAL $a$-find-AOR.I3SG

'I could not find anybody.' (D37.2)

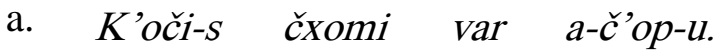
man-DAT fish NEG VAL $a$-take-AOR.I3SG
'The man could not catch fish.' (inf)
b. K'oč-epe-s čxomi var a-č'op-es. man-PL-DAT fish NEG VAL $a$-take-AOR.I3.PL
'The men could not catch fish.' (inf)

In Laz, a verb cannot simultaneously take two core arguments in the dative case, nor can it crossreference two independent arguments by Set II affixes. When a ditransitive verb undergoes potential derivation, two arguments are candidate to be marked by the dative case and crossreferenced by Set II affixes: the (non-canonical) subject and the Recipient. This conflict is resolved by demoting the Recipient, which is encoded as an allative oblique and thus is not indexed on the verb (ex.65).

$$
\begin{array}{lllll}
\text { Bič-epe-S } & \text { xoža-še } & \text { mutu } & \text { var } & a \text {-tkV-es. } \\
\text { boy-PL-DAT } & \text { hoja-ALL } & \text { something } & \text { NEG } & \text { VAL } a \text {-say-AOR.I3.PL }
\end{array}
$$

'The boys couldn't say anything to the hoja.' (Ž.83)

Apart from the potential derivation, which is highly productive, the inversion is found in three tenses (perfect, pluperfect and evidential pluperfect) and with a small set of non-derived verbs. Example (66) illustrates the verb 'give' in the perfect. The $2^{\text {nd }}$ person Recipient appears as an allative oblique $(s k a n-d a)$ (the allative suffix has a special form with $1^{\text {st }}$ and $2^{\text {nd }}$ person pronouns).

$$
\begin{array}{llllllll}
\text { Ma } & \text { skan-da } & \text { sum } & d y a & \text { en } & \text { gyai } & \text { va } & m e-m-i-\check{c} \text {-am- } u-n . \\
\text { 1SG } & \text { 2SG-ALL } & \text { three } & \text { day } & \text { be.I3SG } & \text { food } & \text { NEG } & \text { PV-II1-VAL } u \text {-give-EB-TH-I3SG }
\end{array}
$$

'It has been three days that I haven't given any food to you.' (inf)

\section{Conclusion}

In this paper, I examined the morphosyntactic and lexical properties of ditransitive verbs in Arhavi Laz. We have seen that ditransitive verbs may be non-derived (section 3) or derived by the applicative derivation (section 4). The object properties of the Theme and Recipient in ditransitive construction are summarized in table 9. We can conclude from these data that the alignment type of the ditransitive constructions in Laz is mixed: object properties are distributed on the Theme and the Recipient (section 5). 


\begin{tabular}{|l|c|c|c|c|c|}
\hline & case marking & number agr. & Set II CR & relativization & promotion to subj. \\
\hline monotrans. obj. & absolutive & no & yes & possible & possible \\
\hline Theme & absolutive & no & no & possible & possible \\
\hline Recipient & dative & no & yes $^{\text {a }}$ & possible & impossible \\
\hline alignment & indirective & neutral & secundative $^{\mathrm{a}}$ & neutral & indirective \\
\hline
\end{tabular}

Table 9: Object properties in monotransitive and ditransitive constructions

${ }^{\text {a }}$ This is the most frequent pattern. In the rare cases where the Theme is human (which happens with the verb 'give'), crossreferencing is sensitive to the person hierarchy $1>2>3$.

Haspelmath (2007:92) states that verb-marked person-role inverses have been found in monotransitive constructions only. In section 6, it was argued that in Laz and Jamul Tiipay, person marking of the Theme and Recipient do depend on a $1^{\text {st }}>2^{\text {nd }}>3^{\text {rd }}$ person hierarchy.

The preverbs mo- and $m e$ - basically mark orientation. Their use with the verb 'give' is reminiscent of a direct/inverse marking, although they function according to a $1^{\text {st }}>2^{\text {nd }} / 3^{\text {rd }}$ hierarchy (section 7). Cross-linguistically, orientation-marking expressions are one attested source for the development of direct/inverse markers.

Finally, we have seen that in the inversion construction, the Recipient must be demoted to an oblique position (section 8 ).

\section{Abbreviations}

$\begin{array}{llll}\text { ABS } & \begin{array}{l}\text { absolutive (West Greenlandic), } \\ \text { absolute case (Jamul Tiipay) }\end{array} & \text { NOM } & \text { nominative } \\ \text { ACC } & \text { accusative } & \text { OPT } & \text { optative } \\ \text { ADD } & \text { additive } & \text { PERF } & \text { perfective } \\ \text { ALI } & \text { alienable } & \text { PL } & \text { plural } \\ \text { ALL } & \text { allative } & \text { POSS } & \text { possessive } \\ \text { AOR } & \text { aorist } & \text { PPRF } & \text { pluperfect } \\ \text { CR } & \text { cross-referencing } & \text { PROM } & \text { promised future } \\ \text { DAT } & \text { dative } & \text { PV } & \text { preverb } \\ \text { DEF } & \text { definite } & \text { QUOT } & \text { quotative } \\ \text { DEM } & \text { demonstrative } & \text { SG } & \text { singular } \\ \text { EB } & \text { expanded basis } & \text { SJ } & \text { subject case } \\ \text { EMP } & \text { emphatic } & \text { SUB } & \text { subordinator } \\ \text { ERG } & \text { ergative } & \text { TH } & \text { thematic suffix } \\ \text { EVD } & \text { evidential } & \text { VAL } a & \text { valency marker } a \text { - (potential, middle- } \\ & & & \text { applicative) } \\ \text { FUT } & \text { future } & \text { VAL } i & \text { valency marker } i \text { - (middle) } \\ \text { GEN } & \text { genitive } & \text { VAL } o & \text { valency marker } o \text { - (transitive and applicative) } \\ \text { IMP } & \text { imperative } & \text { VAL } u & \text { valency marker } u \text { - (applicative, inverse tenses) } \\ \text { IMPFT } & \text { imperfect } & \text { I } & \text { cross-referencing affix of Set I } \\ \text { IND } & \text { indicative } & \text { II } & \text { cross-referencing affix of Set II } \\ \text { INSTR } & \text { instrumental } & 1 & 1^{\text {st }} \text { person } \\ \text { INT } & \text { interrogative } & 2 & 2^{\text {nd }} \text { person } \\ & & & \end{array}$




\begin{tabular}{ll} 
IRR & irrealis mood \\
NEG & negation \\
\multicolumn{3}{l}{ References of the examples } \\
D37 & Dumézil 1937 \\
D67 & Dumézil 1967 \\
D72 & Dumézil 1972 \\
K'72 & K'art'ozia 1972 \\
K'93 & K'art'ozia 1993 \\
Ž & Žyent'i 1938 \\
& \\
inf & my informants
\end{tabular}

The number after the full stop refers to the text number. Thus, D37.3 means 'Dumézil (1937), text number 3 '.

\section{References}

Andrews, Peter, compiled and edited with the assistance of Rüdiger Benninghaus. 1989. Ethnic groups in the Republic of Turkey. Wiesbaden: Reichert.

Bodomo, Adams. 1997. The structure of Dagaare. Stanford: CSLI Publications.

Boeder, Winfried. 2005. The South Caucasian languages. Lingua 115.1-2: 5-89.

Croft, William. 1990. Typology and universals. Cambridge: Cambridge University Press.

Čikobava, Arnold. 1936. Č'anuris gramat'ik'uli analizi (t'ekst'ebiturt) [A grammatical analysis of Laz (with texts)]. Tbilisi: Sakartvelos SSR Mecnierebata Ak'ademiis Gamomcemloba.

DeLancey, Scott. 2001. Lectures on functional syntax. Notes for the Summer School of the Linguistic Society of America held at the University of California at Santa Barbara, July 2001. Ms. Available at darkwing.uoregon.edu/ delancey/prohp.html.

Dixon, Robert M. W. and Aikhenvald, Alexandra Y. (eds.). 2000. Changing valency: case studies in transitivity. Cambridge: Cambridge University Press.

Dryer, Matthew. 1986. Primary objects, secondary objects, and antidative. Language 62.4: 808845.

Dumézil, Georges. 1937. Contes lazes. Travaux et mémoires de l'Institut d'Ethnologie, XXVII. Paris.

-----. 1967. Documents anatoliens sur les langues et les traditions du Caucase, IV. Récits lazes (dialecte d'Arhavi). Paris, Presses Universitaires de France.

-----. 1972. Textes en laze d'Ardeşen. Bedi Kartlisa, vol. XXIX-XXX.

Feurstein, Wolfgang. 1983. Untersuchungen zur materiellen Kultur der Lazen. Unpublished master thesis. Albert-Ludwigs Universität, Freiburg.

Fortescue, Michael D. 1984. West Greenlandic. London: Croom Helm.

Harris, Alice C. 1981. Georgian syntax: a study in relational grammar. New York: Cambridge University Press.

----. 1985. Diachronic syntax: the Kartvelian case. Syntax and Semantics 18. New York: Academic Press.

Haspelmath, Martin. 2007. Ditransitive alignment splits and inverse alignment. Functions of Language 14.1: 79-102. 
Holisky, Dee Ann. 1991. Laz. In Harris, Alice C. (ed.). The indigenous languages of the Caucasus. Volume 1, Kartvelian Languages. Academic Resources Corporation.

K'art'ozia, Guram. 1972. Lazuri t'ekst'ebi [Laz texts]. Tbilisi: Sakartvelos SSR Mecnierebata Ak'ademiis Gamomcemloba.

----. 1993. Lazuri t'ekst'ebi [Laz texts]. Tbilisi: Mecniereba.

Kemmer, Suzanne. 1993. The middle voice. John Benjamins.

Kutscher, Silvia. 2001. Nomen und nominales Syntagma im Lasischen. Eine deskriptive Analyse des Dialekts von Ardeşen. München: Lincom Europa (Lincom Studies in Caucasian Linguistics 17).

Lacroix, René. 2009. Description du dialecte laze d'Arhavi (caucasique du sud, Turquie). Grammaire et textes. PhD thesis. University Lyon 2. Available at http://theses.univlyon2.fr/documents/lyon2/2009/lacroix_r.

-----. To appear (a). Origin of Sets I-II plural suffixes in South Caucasian through reanalysis. In Amiridze, Nino and Reseck, Tamar (eds.). Advances in Kartvelian Morphology and Syntax. (Studia Typologica). Berlin: Akademie Verlag.

----. To appear (b). Laz Middle Voice. In Authier, Gilles and Haude, Katharina (eds.). Ergativity and Voice. Mouton de Gruyter.

Malchukov, Andrej, Haspelmath, Martin and Comrie, Bernard. 2007. Ditransitive constructions: a typological overview. ms.

Marr, Nicolas. 1910. Grammatika čanskago (lazskago) jazyka [Grammar of Čan (Laz)]. Materialy po jafetičeskomu jazykoznaniju 2. St. Petersburg: Akademija.

Miller, Amy. 2001. A grammar of Jamul Tiipay. Berlin: Mouton de Gruyter.

Onishi, Masayuki. 2001. Parameters and properties. In Aikhenval, Alexandra Y., Dixon, Robert M. W. and Onishi, Masayuki (eds.). Non-canonical marking of subjects and objects. John Benjamins.

Peterson, David A. 2007. Applicative Constructions. Oxford: Oxford University Press.

Polinsky, Maria. 2005. Applicative Constructions. In Haspelmath, Martin, Dryer, Matthew S., Gil, David and Comrie, Bernard (eds.). The World Atlas of Language Structures. Oxford: Oxford University Press.

Qipšize, Ioseb. 1939. Č'anuri t'ekst'ebi [Laz texts]. Tbilisi: SSRK' Mecnierebata Ak'ademiis Pilialis Gamomcemloba.

Siewierska, Anna. 2004. Person. Cambridge: Cambridge University Press.

Tschenkéli, Kita. 1958. Einführung in die georgische Sprache. Band I: theoretischer Teil. Zürich: Amirani Verlag.

Tuite, Kevin. 1998. Kartvelian Morphosyntax: Number agreement and morphosyntactic orientation in South Caucasian Languages. Studies in Caucasian Linguistics, vol. 12. München: LINCOM Europa.

Van Valin, Robert and LaPolla, Randy. 1997. Syntax. Structure, meaning and function. Cambridge: Cambridge University Press.

Žyent'i, Sergi. 1938. C'anuri t'ekst'ebi (arkabuli k'ilok'avi) [Laz texts (dialect of Arhavi)]. Tbilisi, SSRK' Mecnierebata Ak'ademiis Pilialis Gamomcemloba.

Author's Contact Information:

René Lacroix

Max Planck Institute for Evolutionary Anthropology, Leipzig

lacroix_r@hotmail.com 